\title{
INVESTIGATION INTO THE EFFECTS OF TORREFACTION ON THE QUALITY OF PYROLYSIS PRODUCTS
}

\author{
N. Abdullah ${ }^{1}$, A.A. Safana ${ }^{2 *}$, F. Sulaiman ${ }^{1}$ \\ ${ }^{1}$ School of Physics, Universiti Sains Malaysia, 11800 USM Pulau Pinang, Malaysia \\ ${ }^{2}$ Department of Physics, Federal University Dutse, P.M.B 7156, Dutse, Nigeria
}

(Received: January 2017 / Revised: May 2017 / Accepted: November 2017)

\begin{abstract}
Interest in using biomass energy as an alternative to fossil fuels has advanced in recent years. This study aimed to assess the effects of torrefaction on the quality of pyrolysis products. Oil palm biomass, such as empty fruit bunches (EFB), mesocarp fiber (MF) and palm kernel shell (PKS) were either untreated (untorrefied) or torrefied (treated), and subsequently pyrolyzed. The experiment's conditions for torrefaction were set to be a $220^{\circ} \mathrm{C}$ temperature, a $10^{\circ} \mathrm{C} / \mathrm{min}$ heating rate, and 30 minutes holding time, and for pyrolysis they were set to a $650^{\circ} \mathrm{C}$ temperature, $20^{\circ} \mathrm{C} / \mathrm{min}$ heating rate and 2 hours holding time. The nitrogen flow rate of $2 \mathrm{~L} / \mathrm{min}$ was maintained for both experiments. The results revealed that the torrefaction pretreatment improved the heating value of the torrefied biomass to $18-21 \mathrm{MJkg}^{-1}$ from the previous value of 16-19 $\mathrm{MJkg}^{-1}$ for the untorrefied biomass. During torrefaction, the PKS showed a high solid yield of $95 \%$ due to high lignin content. The higher heating value (HHV) of the biochar and bio-oil derived from untorrefied and torrefied biomass were between $26-30 \mathrm{MJkg}^{-1}$ and $16-17$ $\mathrm{MJkg}^{-1}$ for the former, and $28-31 \mathrm{MJkg}^{-1}$, and $17-20 \mathrm{MJkg}^{-1}$ for the latter. The maximum HHV of $31.2 \mathrm{MJkg}^{-1}$ was obtained from torrefied PKS biochar. The pyrolysis of torrefied biomass gave higher quality biochar and bio-oil compared to untorrefied biomass. The bio-oil acquired from the pyrolysis of the torrefied sample is less acidic and has a higher calorific value in comparison with the bio-oil obtained from the untorrefied sample. MF and PKS have demonstrated a superior outcome after torrefaction. In this way, the PKS and MF were identified as better biomass for torrefaction and pyrolysis compared to EFB.
\end{abstract}

Keywords: Biochar; Bio-oil; Oil palm waste; Pyrolysis;Torrefaction

\section{INTRODUCTION}

For many decades, there has been a tremendous concentration of interest in developing and manufacturing renewable energy. Biomass is formed when carbon dioxide, solar energy (sunlight), and water are mixed via photosynthesis. However, when biomass is burned, carbon dioxide is released into the atmosphere while the chemical energy stored in the biomass is transformed into thermal energy (Chen et al., 2011a). Biomass supplies a clean, renewable energy source the use of which could considerably improve our environment, economy, and energy security through reducing the burning of fossil fuels, the emission of greenhouse gases (GHG), and environmental pollution. Heat and power can be generated from biomass for industrial and domestic purposes. Biomass, together with other fuels, such as wood, energy crops, forest and agricultural residue, and industrial and municipal wastes, could be the main

\footnotetext{
*Corresponding author's email: basalihe2@gmail.com, Tel:+6028227597, Fax: +60217870088

Permalink/DOI: https://dx.doi.org/10.14716/ijtech.v8i8.687
} 
alternatives to coal (Basu et al., 2014). It possible to produce renewable energy resources, especially biomass (Hossain et al., 2017).

In Malaysia, palm oil mills use biomass such as empty fruit bunches (EFB), mesocarp fiber (MF), and palm kernel shell (PKS) as fuel for the power processing plants (Abdullah \&Sulaiman, 2013). In addition, oil palm trunks, fresh fruit bunches (FFB), EFB, oil palm kernels, PKS, oil palm fronds, and other unused parts are scavenged as forest waste biomass for bioethanol production (Hossain et al., 2017a). However, there are problems and challenges associated with the utilization of biomass as a fuel (Chen \&Kuo, 2011; Chen et al., 2011b). The problem of biomass feedstocks with respect to transportation has been a significant issue (Medic et al., 2012). The future potential for using raw biomass as a substitute for fossil fuels, such as coal, is lessened (Chen \&Kuo, 2011). These challenges can be reduced, and biomass quality can be improved through the pretreatment known as torrefaction.

Torrefaction is a thermal pretreatment method for upgrading biomass, where temperatures between $200^{\circ} \mathrm{C}$ and $300^{\circ} \mathrm{C}$ are employed to heat the biomass under an inert or nitrogen atmosphere. The properties of the torrefied biomass rely enormously on the torrefaction temperature (Chen \&Kuo, 2011). An increase in torrefaction temperature increases the fixedcarbon content and heating value, and reduces the moisture, volatile matter, and ash contents. It is also observed that the MF and PKS exhibit an energy yield of $93 \%$ to $100 \%$, while EFB exhibit lower values of $56 \%$ to $83 \%$ after torrefaction. The process results in roughly a $30 \%$ mass loss and $10 \%$ energy loss within the biomass for a variety of gases (Uemura et al., 2011). The decomposition reactions that happen during torrefaction completely dry the biomass, increase the calorific value, and provides biomass that is hydrophobic (Kiel, 2011).

The pyrolysis method results in the creation of three core value-added products, namely biochar, the liquid phase (bio-oil) obtained from the condensed volatile matter, and noncondensable gases, such as $\mathrm{CO}, \mathrm{CO}_{2}, \mathrm{CH}_{4}$, and $\mathrm{H}_{2}$. Biochar is described as charred organic matter, which can be used to improve soil quality, through sequestering carbon in the soil, and reduces GHG emissions. It is a stable carbon compound that can stay in the ground for hundreds of years (Sulaiman et al., 2011; Abdullah \&Sulaiman, 2013). The yield of biochar can be associated with either the primary or secondary decomposition of the raw samples during pyrolysis, which consequently influences the pyrolysis conversion processes. Moreover, the deportment of cellulose, hemicelluloses, and lignin during the pyrolysis plays a vital function in the yield of biochar (Abnisa et al., 2013, Angin, 2013). The high yield of biochar at low temperatures demonstrates that the material has been only partially pyrolyzed (Angin, 2013). During the pyrolysis of the PKS, it is observed that the charcoal content decreases profoundly from $36.7 \mathrm{wt} \%$ as the temperature is raised from $300^{\circ} \mathrm{C}$ to $600^{\circ} \mathrm{C}$. As the temperature increased more in advance, the charcoal yield reduced slightly to only $1.5 \mathrm{wt} \%$ of PKS mass being lost when the final temperature rose from $600^{\circ} \mathrm{C}$ to $1000^{\circ} \mathrm{C}$. It appears that the devolatilization of the PKS was focused at lower temperatures $\left(300-600^{\circ} \mathrm{C}\right)$. It is reported that, during the pyrolysis process, cellulose, hemicelluloses, and lignin are respectively found to demonstrate the highest to the lowest disintegration rates. At a temperature of more than $400^{\circ} \mathrm{C}$ the cellulose content is almost totally pyrolyzed with a little quantity of the solid remaining (Yang et al., 2006).

Bio-oil or bio-crude is described as a dark brown liquid with a heating value similar to that of oxygenated fuels, such as methanol and ethanol (Aziz et al., 2013). It is considered to be an alternative to fossil fuels, such as petroleum and diesel, for producing power (Aziz et al., 2013; Xiu\&Shahbazi, 2012). Jahirul et al. (2012) note that cellulose is principally responsible for biooil production during the pyrolysis of biomass (at around $500^{\circ} \mathrm{C}$ ). However, the best quality bio-oil can be generated from biomass with high lignin content. Biomass with a large amount of 
volatile matter generates large amounts of bio-oil and syngas. The moisture content of biomass influences the heat transfer process and has significant effects on product distribution. In addition, an increase in moisture content increases the liquid product yield, and reduces the yield of solid and gas products. This could be associated with the huge amount of condensate water generated from the moisture in the liquid phase. Biomass containing only a small amount of minerals and nitrogen is desirable for bio-oil and syngas generation. In this study, raw biomass was pretreated via torrefaction and then pyrolyzed. The treated and untreated biomasses were pyrolyzed under the same pyrolysis conditions, and the experiments' results were analyzed and compared. The purpose of this study is to assess the effect of torrefaction on the products of pyrolysis, mainly biochar and bio-oil.

\section{METHODOLOGY}

\subsection{Material and Sample Preparation}

The oil palm samples studied were obtained from a palm oil mill located in NibongTebal, Pulau Pinang, Malaysia. The moisture contents of the biomass as received were 15, 13.1, and 11.3 $\mathrm{wt} \%$ for EFB, MF, and PKS, respectively. The samples were dried for 24 hours at $105^{\circ} \mathrm{C}$ for moisture removal. A thermogravimetric analysis (TGA) was performed on the sample using a Perkin Elmer STA 6000 thermogravimetric analyzer. Thermal analysis was used to examine the thermal performance of the samples by observing the weight alteration that happened as the samples were heated, with respect to hemicellulose, cellulose, and lignin, and identifying their thermal degradation behavior. The analysis was carried out in the presence of a nitrogen $\left(\mathrm{N}_{2}\right)$ gas flow under a $5^{\circ} \mathrm{C} / \mathrm{min}$ heating rate, with a sample size of $250-355 \mu \mathrm{m}$ and the samples were heated from ambient temperature to about $900^{\circ} \mathrm{C}$.

A proximate analysis was carried out in accordance with ASTM E871 for moisture content, ASTM E872 for volatile matter content, and ASTM E1755-01 for ash content, from which the difference was used to determine the amount of fixed carbon. An elemental analysis was conducted to analyze the percentages of carbon $(\mathrm{C})$, hydrogen $(\mathrm{H})$, nitrogen $(\mathrm{N})$, sulfur $(\mathrm{S})$, and oxygen (O). It was performed using a Perkin Elmer 2400 analyzer, and 2-2.8 $\mathrm{mg}$ of sample was used to measure the percentage weight of each element present. The higher heating value (HHV) was determined using bomb calorimeter system IKA C 200, and oxygen station C248 with an empty water hose. For each test run, 0.5 to $0.8 \mathrm{~g}$ of the sample was measured and placed in the crucible joined to the thread from the ignition wire, which was then closed, and oxygen gas was pumped in.

\subsection{Experiment System}

The torrefaction experiment was conducted three times separately using a stainless-steel reactor of $150 \mathrm{~mm}$ length and $70 \mathrm{~mm}$ internal diameter; about $180 \mathrm{~g}$ of raw biomass was weighed and placed inside the electric furnace. The reactor was heated at $220^{\circ} \mathrm{C}$ for 30 minutes and at a heating rate of $10^{\circ} \mathrm{C} / \mathrm{min}$. The torrefied (treated) and untreated samples were used as the feedstock for the pyrolysis experiments. The pyrolysis experiments were performed by placing $100 \mathrm{~g}$ of the torrefied biomass into a smaller reactor with a diameter of $110 \mathrm{~mm}$ and length of $190 \mathrm{~mm}$. The electric furnace was heated to $650^{\circ} \mathrm{C}$ for a holding time of 1 hour and at a $20^{\circ} \mathrm{C} / \mathrm{min}$ heating rate. For both torrefaction and pyrolysis, the reactor temperature was monitored using a K-type thermocouple, and nitrogen $\left(\mathrm{N}_{2}\right)$ was used as the reaction gas at a rate of 2 liters/min. The pyrolysis products (bio-oil and noncondensable gases) were passed through a cooling system, which was regulated at $5^{\circ} \mathrm{C}$. The bio-oil produced was condensed and collected in flasks numbered 1 and 2, and the noncondensable gases exited the system through the gas outlet. 


\subsection{Characterization}

The water content of the bio-oils was determined using Karl Fischer titration (870 KF Titrino Plus) water determination. The bio-oils were initially titrated with a standard Karl Fischer reagent to an electrometric endpoint. Exactly $1 \mathrm{~g}$ of sample was weighed out into a dry Erlenmeyer flask fitted with a septum stopper. It was treated with about 20-25 g of dry solvent (mixture), the container was then sealed and the contents mixed. Part of the mixture is drawn off in a dry syringe, and the syringe and its contents are tared. Some of each mixture is separately injected into the titration vessel and titrated. The amount of sample injected is determined by back-weighing the syringe. The densities of the bio-oils were measured at room temperature $\left(25^{\circ} \mathrm{C}\right)$ using a portable density meter (DMA 35 Portable Density/Specific Gravity/Concentration Meter). The DMA 35 measured the density of the liquids in $\mathrm{g} / \mathrm{cm}^{3}$ or $\mathrm{kg} / \mathrm{m}^{3}$ according to the oscillating u-tube principle.

A temperature sensor measured the temperature of the sample at the position of the measuring cell. For each experiment, the measuring cell was filled with an individual sample using the built-in pipette-style pump or a syringe. The readings were taken directly from the screen. A pH meter with an electrode and temperature sensors was used to measure the $\mathrm{pH}$ of the bio-oils. Each bio-oil sample was separately placed into a beaker, and the electrode and temperature probe were immersed into the sample solution. The solution was stirred moderately until the meter sensors displayed a stable reading icon on the screen. This measurement was conducted at room temperature. The viscosity of the bio-oils was determined using a portable Rion viscometer (VT 03/04). The viscometer used can measure a thickness range from 15-150 cP, and includes parts such as cups $\mathrm{A}$ and $\mathrm{B}$, a bracket for attachment, and cylindrical rotors numbered 1-5. About $120 \mathrm{ml}$ of bio-oil was measured at $25^{\circ} \mathrm{C}$ and placed in the cup up to its edge. The cup was attached to the bracket and connected to the rotor, then the power was switched on and it was run for some seconds. The viscosity values were taken directly from the meter by rotating a rotor in the sample fluids, which causes viscous resistance.

The biochars acquired were characterized by proximate, elemental analyses, and calorific values in line with the previously described procedures. Scanning electron microscopy (SEM) was employed to determine the porosity and morphology of the biochar. This was conducted using an EVO/MA10 model SEM, which was controlled to be at a $20 \mathrm{kV}$ accelerated voltage and a magnification of $500 \mathrm{mag}$. Before the SEM, the sample was sieved to a uniform size of about $150 \mu \mathrm{m}$ and dried for 24 hours at $105^{\circ} \mathrm{C}$ in an oven. There was no coating applied before the SEM analysis.

\section{RESULTS AND DISCUSSION}

\subsection{Basic Characteristics of OilPalmSamples}

Figure 1 displays the TGA and differential thermogravimetry (DTG) curves of the sample. The samples showed similar behavior during pyrolysis. The first small peak corresponds to the evaporation of moisture and the early weight loss at a temperature lower than $150^{\circ} \mathrm{C}$ for all the palm biomass samples. The degradation of hemicelluloses commences at temperatures of around $270^{\circ} \mathrm{C}$ for $\mathrm{EFB}, 290^{\circ} \mathrm{C}$ for $\mathrm{MF}$, and $300^{\circ} \mathrm{C}$ for the PKS. It is reported by Sulaiman and Abdullah (2011) that DTG curves for PKS and MF attain separate peaks for hemicellulose at around $300^{\circ} \mathrm{C}$ and cellulose above $300^{\circ} \mathrm{C}$. In the author's study, the peak at around $310^{\circ} \mathrm{C}$ and the two peaks at $360^{\circ} \mathrm{C}$ correspond to the degradation of cellulose for $\mathrm{EFB}, \mathrm{MF}$, and $\mathrm{PKS}$, respectively. Though the breakdown of cellulose and hemicelluloses is a constant progression, the weight loss of these constituents was sustained throughout nearly the whole heating period. However, the maximum decline speeds of the celluloses are between 300 and $360^{\circ} \mathrm{C}$, and for the hemicelluloses they are between 270 and $300^{\circ} \mathrm{C}$. The degradation of lignin is seen at $650{ }^{\circ} \mathrm{C}$, but PKS shows a high resistance to temperature due to its high lignin content. The total weight 
losses between $100^{\circ} \mathrm{C}$ and $450^{\circ} \mathrm{C}$ are $78.6 \%, 75.71 \%$, and $98.5 \%$ for $\mathrm{EFB}, \mathrm{MF}$, and $\mathrm{PKS}$, respectively.
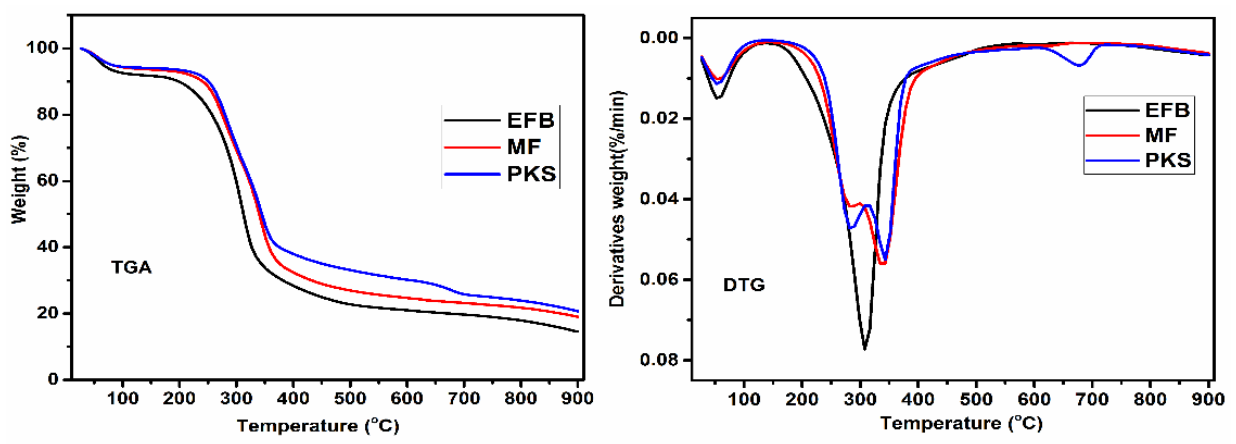

Figure 1 Thermal analysis (TGA and DTG curves)

Table 1 shows the results of the proximate analysis of the raw and torrefied samples. It can be observed that the volatile matter and moisture contents in the raw samples were reduced in the torrefied samples. However, the fixed-carbon and ash contents increased in the torrefied samples.

Table 1 Physiochemical analysis of raw and torrefied $\left(220^{\circ} \mathrm{C}\right)$ samples

\begin{tabular}{lccccccccc}
\hline \multirow{3}{*}{ Biomass } & \multicolumn{3}{c}{ Elemental analysis (wt\%) } & \multicolumn{5}{c}{ Proximate analysis (wt\%) } \\
\cline { 2 - 9 } & Carbon & Hydrogen & Nitrogen & Oxygen & Moisture & Volatile & Ash & $\begin{array}{c}\text { Fixed } \\
\text { carbon }\end{array}$ & $\begin{array}{c}\text { HHV } \\
\left(\mathrm{MJkg}^{-1}\right)\end{array}$ \\
\hline EFB Raw & 42.80 & 6.20 & 0.47 & 50.44 & 7.30 & 82.40 & 7.51 & 10.09 & 16.90 \\
Torrefied & 43.80 & 5.80 & 0.59 & 49.81 & 5.90 & 73.60 & 7.70 & 18.70 & 19.10 \\
MF Raw & 46.37 & 5.52 & 0.61 & 47.47 & 6.20 & 77.15 & 7.02 & 15.83 & 19.06 \\
Torrefied & 47.92 & 5.31 & 1.03 & 45.74 & 3.90 & 70.80 & 7.60 & 21.60 & 21.20 \\
PKS Raw & 50.29 & 6.34 & 0.48 & 42.81 & 4.70 & 75.40 & 8.70 & 15.90 & 19.50 \\
Torrefied & 52.12 & 6.12 & 1.10 & 40.66 & 2.81 & 71.90 & 7.33 & 20.77 & 18.80 \\
\hline
\end{tabular}

The elemental compositions and HHV of the raw and torrefied samples are also given in Table 1. This reveals that the weight percentages of the oxygen and carbon contents in the torrefied samples decrease and increase, respectively. It is explained that the thermal degradation during torrefaction consumes a partial amount of the oxygen content in biomass (Chen et al., 2011a). The degradation of hemicellulose and cellulose during torrefaction is more pronounced than that of lignin (Chen et al., 2011a). The HHV has improved in the torrefied sample. However, the improvement is slightly higher for EFB than for MF or PKS. This could be due to the high moisture content in EFB, which was reduced in the torrefied sample.

The torrefaction and pyrolysis product yields are shown in Table 2. The solid, liquid, and gas yields from the torrefaction are between $85-95 \%, 0-5 \%$, and 5-10 \%, respectively. The DTG results identify that, during the pyrolysis process, the temperature range of $30-150^{\circ} \mathrm{C}$ is associated with the evaporation of moisture, and the temperature range of $150-270^{\circ} \mathrm{C}$ is associated with the decomposition of hemicelluloses, celluloses, and some lignin. It can also be seen that untreated samples produced higher amount of liquids and gases, while the treated samples generated more solid (biochar) content. Therefore, an effect of torrefaction is that the treated samples with less volatile matter and more fixed-carbon contents favor biochar production. 
Table 2 Torrefaction and pyrolysis product yields

\begin{tabular}{cllrc}
\hline Material $(\%)$ & Temperature $\left({ }^{\circ} \mathrm{C}\right)$ & Solid & Liquid & Gas \\
\hline \multirow{3}{*}{ EFB } & 220 & 85.00 & 5.00 & $5.00-10.00$ \\
& 650 (untreated) & 26.61 & 43.41 & 29.98 \\
& 650 (treated) & 30.84 & 42.02 & 27.11 \\
\hline \multirow{3}{*}{ MF } & 220 & 90.00 & 0.00 & 10.00 \\
& 650 (untreated) & 33.94 & 40.99 & 25.07 \\
& 650 (treated) & 36.66 & 40.27 & 23.07 \\
\hline \multirow{3}{*}{ PKS } & 220 & 95.00 & 0.00 & 5.00 \\
& 650 (untreated) & 38.91 & 38.91 & 22.18 \\
& 650 (treated) & 39.87 & 39.04 & 21.09 \\
\hline
\end{tabular}

\subsection{BiocharCharacterization}

Table 2 shows the physical and chemical characteristics of the biochars. The results of the proximate analysis reveal that the biochars derived from the treated samples contain less volatile matter and more fixed-carbon contents than the biochars from untreated samples. The same scenario is observed for the chemical composition and heating values.

Table 3 Physical and chemical characteristics of biochars

\begin{tabular}{lrrrrrr}
\hline \multicolumn{1}{c}{ Sample $(\mathrm{wt} \%)$} & \multicolumn{2}{c}{ EFB } & \multicolumn{2}{c}{ MF } & \multicolumn{2}{c}{ PKS } \\
\hline \multicolumn{1}{c}{ Preparation $\left({ }^{\circ} \mathrm{C}\right)$} & Untreated & Treated & Untreated & Treated & Untreated & Treated \\
\hline Proximate $^{\mathrm{a}}$ & & & & & & \\
Volatile matter $_{\text {Ash content }}$ & 43.80 & 22.20 & 16.50 & 15.07 & 15.15 & 14.76 \\
Fixed carbon $^{\mathrm{b}}$ & 12.20 & 12.50 & 11.80 & 10.51 & 12.30 & 11.76 \\
Elements $^{\mathrm{a}}$ & 44.00 & 45.30 & 71.70 & 74.42 & 72.55 & 73.48 \\
Carbon & & & & & & \\
Hydrogen & 66.50 & 67.20 & 74.30 & 75.20 & 83.60 & 81.20 \\
Nitrogen & 4.01 & 3.21 & 3.61 & 4.20 & 6.220 & 5.51 \\
Oxygen $^{\mathrm{b}}$ & 0.49 & 1.12 & 0.52 & 0.49 & 1.12 & 0.92 \\
HHV(MJ/kg) & 29.00 & 28.47 & 21.57 & 20.11 & 9.06 & 12.37 \\
\hline
\end{tabular}

${ }^{\mathrm{a}}$ Weight percentage (wt $\left.\%\right),{ }^{\mathrm{b}} \mathrm{Calculated}$ using the difference

The structure of holes and shapes generated on the surface of biochar through pyrolysis can be observed on SEM images. Table 1 and Table 3 display the volatile matter contents of raw biomass, torrefied samples, and biochars. The volatile matter contents of the raw biomass studied were reduced in the torrefied samples. During the pyrolysis of the untreated samples, the volatile matter contents produced is found to be $43.8 \mathrm{wt} \%$ for EFB, $16.5 \mathrm{wt} \%$ for MF, and $15.15 \mathrm{wt} \%$ for PKS. For the pyrolysis of the treated samples, the volatile matter released was $22.2 \mathrm{wt} \%$ for EFB, $15.07 \mathrm{wt} \%$ for MF, and $14.76 \mathrm{wt} \%$ for PKS. This implies that a high quantity of volatile matter is produced during the pyrolysis of the untreated samples. It can also be seen clearly from the SEM images in Figure 2, that the holes in mages (a) and (e) for the biochar obtained from the untreated samples are few and scattered. SEM Image in (c) showed many holes, mostly arranged on one side of the sample. The average size of the holes is between 10 to $14 \mu \mathrm{m}$. For the biochar derived from the treated samples, the size of the holes for (b), (d) and (f) images are found to be uniform and with an average size of 12-13 $\mu \mathrm{m}$ for EFB, 4-5 $\mu \mathrm{m}$ for MF and 5-7 $\mu \mathrm{m}$ for PKS. The large holes in EFB may be due to the high content of volatile matter in the raw material (Table 1), which was produced and released during pyrolysis. Sohi et al. (2009) reported that the porous structure of biochar can explain its influence on soil 
water retention and adsorption ability. Biochar produced at low temperatures is, however, hydrophobic, and this might reduce its capacity to retain water (Sohi et al., 2009).
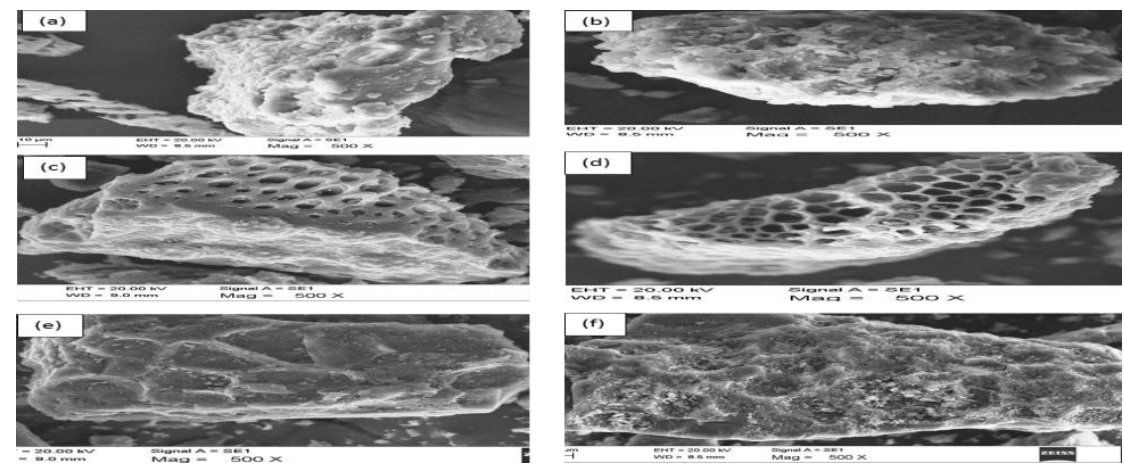

Figure 2 SEM images for: (a) untreated EFB biochar; (b) treated EFB biochar; (c) untreated MF biochar; (d) treated MF biochar; (e) untreated PKS biochar; and (f) treated PKS biochar

\subsection{Bio-oil Characterization}

The physical properties of bio-oil are shown in Table 4; the density, viscosity, $\mathrm{pH}$, and calorific value of the bio-oils derived from the treated samples are slightly higher than for the bio-oils from the untreated samples. This could be because of the low water content in the bio-oils derived from the treated samples. However, the pH and HHV of PKS bio-oil are exceptions. There is not much difference in the viscosities of the bio-oils obtained from untreated and treated samples. The effect of torrefaction as a pretreatment is shown in Table 4. The viscosity of bio-oils is comparatively higher than that of other liquid fuels, such as diesel and gasoline (Thangalazhy-Gopakumar et al., 2010).

Table 4 Physical properties of bio-oils

\begin{tabular}{llccccc}
\hline Samples & Preparation & $\begin{array}{c}\text { Density } \\
\left(25^{\circ} \mathrm{C}, \mathrm{gcm}^{-3}\right)\end{array}$ & $\begin{array}{c}\text { Water } \\
\text { content }(\%)\end{array}$ & $\begin{array}{c}\text { Viscosity } \\
\left(25^{\circ} \mathrm{C}, \mathrm{cP}\right)\end{array}$ & $\mathrm{pH}$ & $\mathrm{HHV}\left(\mathrm{MJkg}^{-1}\right)$ \\
\hline \multirow{2}{*}{ EFB } & Untreated & 1.029 & 47 & 1.90 & 3.10 & 17.40 \\
& Treated & 1.039 & 30 & 2.01 & 3.48 & 18.98 \\
\hline \multirow{2}{*}{ MF } & Untreated & 1.028 & 43 & 2.00 & 3.67 & 16.21 \\
& Treated & 1.035 & 35 & 1.92 & 3.84 & 19.01 \\
\multirow{2}{*}{ PKS } & Untreated & 1.038 & 40 & 2.03 & 3.07 & 17.93 \\
& Treated & 1.054 & 33 & 2.30 & 2.85 & 20.86 \\
\hline
\end{tabular}

The densities of the bio-oils are in the range of $1.028-1.038 \mathrm{gcm}^{-3}$ for the bio-oils obtained from the untreated samples and $1.035-1.054 \mathrm{gcm}^{-3}$ for the bio-oils obtained from the treated samples. The $\mathrm{pH}$ values for the bio-oils derived from untreated and treated samples are from 2.85-3.84. It is stated that the $\mathrm{pH}$ value of PKS bio-oils is between 2.9 to 3.3 (Aziz et al., 2013). The pH value of bio-oil is incomparable to commercial diesel because of the presence of organic acids in the bio-oils (Aziz et al., 2013). The bio-oils derived from the treated samples have higher calorific value than the bio-oils from untreated samples. The high water content disqualifies bio-oils from a direct application as fuel. Table 5 presents the elemental composition of the biooils obtained from treated and untreated biomass. 
Table 5 Chemical composition of bio-oils

\begin{tabular}{llccccc}
\hline \multirow{2}{*}{ Bio-oil } & \multirow{2}{*}{ Preparation } & \multicolumn{5}{c}{ Elemental analysis (wt\%) } \\
\cline { 3 - 7 } & & Carbon & Hydrogen & Nitrogen & Oxygen & Sulfur \\
\hline \multirow{2}{*}{ EFB } & Untreated & 25.97 & 9.85 & 0.96 & 63.11 & 0.11 \\
& Treated & 28.02 & 10.13 & 1.67 & 60.09 & 0.09 \\
\hline \multirow{2}{*}{ MF } & Untreated & 26.07 & 8.76 & 1.01 & 64.08 & 0.08 \\
& Treated & 29.22 & 9.37 & 1.10 & 60.11 & 0.10 \\
\hline \multirow{2}{*}{ PKS } & Untreated & 24.98 & 10.01 & 0.89 & 64.00 & 0.12 \\
& Treated & 30.51 & 10.70 & 0.71 & 57.99 & 0.09 \\
\hline
\end{tabular}

\section{CONCLUSION}

Torrefaction, as a pretreatment, has the potential to improve the quality of biomass. The pyrolysis of the treated biomass has revealed that the pretreatment of biomass has led to an improvement in the products of pyrolysis. The fixed-carbon contents and calorific values for the biochars and bio-oils derived from the treated samples have improved significantly. The biochar derived from treated PKS contained the highest calorific value among all the biochars of 31.2 $\mathrm{MJkg}^{-1}$. The bio-oil obtained from the pyrolysis of the treated samples was less acidic and contained a higher calorific value compared to the bio-oil obtained from the untreated samples. MF and PKS have shown a better result than EFB after being treated via torrefaction. Therefore, the PKS and MF biomass types are better suited to undergoing torrefaction and pyrolysis than EFB.

\section{ACKNOWLEDGMENT}

The authors wish to express their gratitude to the UniversitiSains Malaysia for financing this research through grants RUI [1001/PFIZIK/814250], [1001/PFIZIK/814228], and FRGS [203/PFIZIK/6711410].

\section{REFERENCES}

Abdullah, N., Gerhauser, H., 2008. Bio-oil Derived from Empty Fruit Bunches. Fuel, Volume 87, pp. 2606-2613

Abdullah, N., Sulaiman, F., 2013. Chapter 3. The Oil Palm Wastes in Malaysia. Miodrag Darko Matovic. Biomass Now- Sustainable Growth and Use. Pp. 978-953

Abnisa, F., Arami-Niya, A., Daud, W.W., Sahu, J., 2013. Characterization of Bio-oil and Biocharfrom Pyrolysis of Palm Oil Wastes. BioEnergy Research, Volume 6(2), pp. 830-840

Adisak, P., James, O.T., Anthony, V.B., 2006. Fast Pyrolysis of Agricultural Residues from Cassava Plantation for Bio-oil Production. In: The $2^{\text {nd }}$ Joint International Conference on Sustainable Energy and Environment (SEE 2006). 21-23 November 2006, Bangkok, Thailand

Angin, D., 2013. Effect of Pyrolysis Temperature and Heating Rate on Biochar Obtained from Pyrolysis of Safflower Seed Press Cake. Bioresource Technology, Volume 128, pp. 593597

Atzeni, E., Iuliano, L., Minetola, P., Salmi, A., 2010. Redesign and Cost Estimation of Rapid Manufactured Plastic Parts. Rapid Prototyping Journal, Volume 16(5), pp. 308-317

Aziz, S.M.A., Wahi, R., Ngaini, Z., Hamdan, S., 2013. Bio-oils from Microwave Pyrolysis of Agricultural Wastes. Fuel Processing Technology, Volume 106, pp. 744-750

Basu, P., Sadhukhan, A.K., Gupta, P., Rao, S., Dhungana, A., Acharya, B., 2014. An Experimental and Theoretical Investigation on Torrefaction of a Large Wet Wood Particle. BioresourTechnol, Volume 159, pp. 215-222 
Chen, W-H., Cheng, W-Y., Lu, K-M., Huang, Y-P., 2011a. An Evaluation on Improvement of Pulverized Biomass Property for Solid Fuel through Torrefaction. Applied Energy, Volume 88, pp. 3636-3644

Chen, W-H., Hsu, H-C., Lu, K-M., Lee, W-J., Lin, T-C., 2011b. Thermal Pretreatment of Wood (Lauan) Block by Torrefaction and Its Influence on the Properties of The Biomass. Energy, Volume 36, pp. 3012-3021

Chen, W-H., Kuo, P-C., 2011. Torrefactionand Co-torrefaction Characterization of Hemicellulose, Cellulose and Lignin as Well as Torrefaction of Some Basic Constituents In Biomass. Energy, Volume 36, pp. 803-811

Hossain, N., Haji J. Z., Mahlia, T.M.I., 2017a. A Review of Bioethanol Production from Plantbased Waste Biomass by Yeast Fermentation. International Journal of Technology, Volume 8(1), pp. 5-18

Hossain, N., Jalil, R., Mahlia, T.M.I., Juliana, Z., 2017. Calorific Value Analysis of AzadirachtaExcelsa and EndospermumMalaccense as Potential Solid Fuels Feedstock. InternationalJournal of Technology, Volume 4, pp. 634-643

Jahirul, M., Rasul, M., Chowdhury, A., Ashwath, N., 2012. Biofuels Production through Biomass Pyrolysis - A Technological Review. Energies, Volume 5, pp. 4952-5001

Kiel, J.H.A., Van der Stelt, M.J.C., Gerhauser, H., Ptasinski, K.J., 2011. Biomass Upgrading by Torrefaction for the Production of Biofuels: A Review. Biomass and Bioenergy, Volume 35, pp. 3748-3762

Kong, S-H., Loh, S-K., Bachmann, R.T., Rahim, S.A., Salimon, J., 2014. Biocharfrom Oil Palm Biomass: A Review of Its Potential and Challenges. Renewable and Sustainable Energy Reviews, Volume 39, pp. 729-739

Mahmood, W., Ariffin, M., Harun, Z., Ishak, N., Ghani, J., Rahman, M., 2015. Characterisation and Potential Use of Biochar from Gasified Oil Palm Wastes. Journal of Engineering Science and Technology, Volume 10, pp. 45-54

Medic, D., Darr, M., Shah, A., Potter, B., Zimmerman, J., 2012. Effects of Torrefaction Process Parameters on Biomass Feedstock Upgrading. Fuel, Volume 91, pp. 147-154

Sohi, S., Lopez-Capel, E., Krull, E., Bol, R., 2009. Biochar, ClimateChange and Soil: A Review to GuideFutureResearch. CSIRO Glen Osmond, Australia

Sulaiman, F., Abdullah, N., 2011. Optimum Conditions for Maximising Pyrolysis Liquids of Oil Palm Empty Fruit Bunches. Energy, Volume 36, pp. 2352-2359

Sulaiman, F., Abdullah, N., Gerhauser, H., Shariff, A., 2011. An Outlook of Malaysian Energy, Oil Palm Industry and Its Utilization of Wastes as Useful Resources. Biomass and bioenergy, Volume 35, pp. 3775-3786

Thangalazhy-Gopakumar, S., Adhikari, S., Ravindran, H., Gupta, R.B., Fasina, O., Tu, M., Fernando, S.D., 2010. Physiochemical Properties of Bio-oil Produced at Various Temperatures from Pine Wood using an Auger Reactor. BioresourceTechnology, Volume 101, pp. 8389-8395

Uemura, Y., Omar, W.N., Tsutsui, T., Yusup, S.B., 2011. Torrefaction of Oil Palm Wastes. Fuel, Volume 90, pp. 2585-2591

Wan Asma Ibrahim, S.P.C., 2012. Converting Waste Oil Palm into a Resource. Final Report, UNEP, 2012

Xiu, S., Shahbazi, A., 2012. Bio-oil Production and UpgradingResearch: A Review. Renewable and Sustainable Energy Reviews, Volume 16, pp. 4406-4414

Yang, H., Yan, R., Chen, H., Lee, D.H., Liang, D.T., Zheng, C., 2006. Mechanism of Palm Oil Waste Pyrolysis in a Packed Bed. Energy \& Fuels, Volume 20, pp. 1321-1328

Yuliansyah, A.T., Hirajima, T., 2012. Efficacy of Hydrothermal Treatment for Production of Solid Fuel from Oil Palm Wastes.INTECH Open Access Publisher. DOI: 10.5772/50581 